\title{
Can resistin be used as a biomarker in coronary artery disease: A review
}

\author{
Turgay Yildırım Ö* $^{*}$ \\ Eskisehir State Hospital, Cardiology Department, Eskisehir, Turkey
}

\begin{abstract}
Resistin was first discovered as a mediator of insulin resistance and obesity in rodents but the effects of resistin on human is still been investigated. It is mostly associated with inflammation in humans. Several publications suggest its relationship with cardiovascular diseases and many systemic disorders. In this review we focused on resistin and coronary artery disease.
\end{abstract}

\section{Resistin as a peptide}

Resistin was discovered in 2001 in rodent experiments and taken its name from its relationship with insulin resistance. Human resistin is a cysteine-rich peptide consisting of 108 amino acid sequences at a weight of $12.5 \mathrm{kDa}$. Human and rodent resistin are $59 \%$ similar in amino acid level [1]. The presence of different promoter regions of rodent and human resistin genes suggests differences in tissue distribution, function, and regulatory mechanisms [1,2]. In humans resistin is secreted from peripheral blood mononuclear cells, macrophages and bone marrow cells $[3,4]$.

Several studies have shown that serum resistin concentration is increased in obese and diabetic patients [5-7]. Resistin has also been associated with atherosclerosis and cardiovascular disease development, nonalcoholic fatty liver disease, rheumatologic diseases, malign tumors, asthma, inflammatory bowel disease and chronic renal failure $[8,9]$.

\section{Resistin and coronary artery disease relationship}

The first important study showing the relationship between atherosclerosis and resistin was performed by Reilly et al. [10] in 2005. In this study, there was a relationship between increased resistin level and coronary calcium score. Afterwards, several studies investigating the presence or severity of coronary artery disease (CAD) and resistin relationship were performed. In a study conducted by Ohmori et al. [11], it was found that as the number of vessels with more than $50 \%$ stenosis increases, the resistin level also increases. Wang et al. [12] grouped 220 patients as control group, stable angina pectoris group and acute coronary syndrome group and performed coronary angiography. Resistin levels were higher in the acute coronary syndrome group than the other groups, while no significant difference was found between the control group and the stable angina pectoris group. Also results of this study showed that as the number of coronary arteries with more than $50 \%$ stenosis increases, the level of resistin also increases.

In a follow-up study of patients with percutaneous coronary intervention, resistin levels were found to be independent predictors of MACE (major adverse cardiac events), but there was no relationship between stent restenosis and resistin levels in the same study [13]. Another study in diabetic patients found an association between resistin levels and stent restenosis [14].
In a study conducted by Chu et al. [15], resistin levels have been significantly increased at 24 hours and remained higher for 1 week at patients with acute coronary syndrome when compared to control group. This increase was found to be higher in myocardial infarction patients than unstable angina pectoris patients. In another study conducted by Lubos et al. [16], resistin levels were found to be higher in unstable angina, ST elevation and non-ST elevation myocardial infarction compared to stable angina patients. It was found that there was a relationship between the resistin level and the incidence of cardiovascular death after 2.6 years of follow-up. Another study comparing unstable angina patients with stable angina and control group found that patients with unstable angina had a higher level of resistin. There was no significant difference in resistin levels in patients with stable angina and the control group [17].

In a study conducted by Zhang et al. [18], 980 patients with CAD were followed for an average of 6.1 years. In this follow-up, patients with the highest quartile of resistin levels were found to have the highest risk of heart failure and mortality. In a study conducted by Wu et al. [19], 108 patients with Ejection fraction $(\mathrm{EF})<50 \%$ were followed for an average of 776 days. In this study, mortality was found to be higher in the group with high resistin level. In another study, a statistical association of resistin levels with MACCE (major adverse cerebrovascular and cardiac events) was found in patients with multivessel disease over a year's follow-up [20].

There are also a number of studies showing no relationship between resistin and CAD. Yaturu et al. [21] shows the relationship between inflammatory process and resistin in CAD patients. This study compared the patient group with $57 \mathrm{CAD}$ and 45 control patients. The diagnosis of CAD was based on the myocardial infarction history, myocardial perfusion scintigraphy or coronary angiography results. In this study, there was no significant difference in resistin levels in patients

${ }^{\star}$ Correspondence to: Özge Turgay Yildirim, Eskisehir State Hospital, Cardiology Department, Eskisehir, Turkey, E-mail: ozgeturgay@gmail.com

Key words: resistin, atherosclerosis, coronary artery disease, inflammation

Received: July 03, 2018; Accepted: July 17, 2018; Published: July 19, 2018 
with and without CAD. In this study, resistin levels were strongly correlated with inflammatory markers such as TNF- $\alpha$ and CRP. Hoelfe et al. [22] evaluated resistin levels in 547 patients who underwent coronary angiography for stable CAD assessment and patients were followed up for 4 years for major cardiac event frequency. In this study, resistin was not associated with coronary artery stenosis. Also resistin had no relationship for future vascular events according to results of 4-year follow-up. In this study resistin was also significantly correlated with CRP levels. Another study evaluated 128 stable angina pectoris patients according to coronary angiography results. This study grouped patients according to their CAD severity. This study also showed no relationship between resistin levels and presence or severity of CAD [23]. In a study conducted by Pischon et al. [24] on female patients, 185 patients with coronary artery disease and control group consisting of 227 patients were compared with each other. At initial analysis there was a significant relationship between resistin level and coronary artery disease but after adjustments for CRP, the association was no longer significant. LURIC (The Ludwigshafen Risk and Cardiovascular Health Study) study [25] evaluated 1162 patients according to their coronary angiography results. CAD is defined as having $\geq 20 \%$ lesion in at least one coronary artery. According to the result of angiography, 911 patients were taken into the CAD group and 251 patients were defined in the non-CAD group. When resistin levels were examined, there was no significant difference between the groups. There was no significant difference in resistin levels between the groups when the coronary artery stenosis limit was $\geq 50 \%$. There was also no relationship in terms of resistin levels when acute coronary syndrome and stable angina patients were compared.

\section{Conclusion}

There are several studies investigating resistin, atherosclerosis, and coronary artery disease. There are both positive resulted studies and negative ones. It is noteworthy that, in studies showing the association, the relationship is often more prominent in acute coronary syndromes. There are also studies showing that resistin levels are higher in patients with stable coronary artery disease, as well as studies showing that they are similar to normal populations. Furthermore, when analysis is done considering CRP values, the association of resistin often disappears in coronary artery disease patients. This suggests that the inflammation parameters and resistin are strongly related. More work needs to be done to clarify this issue and the effect of inflammation parameters should be considered in future studies.

\section{References}

1. Ghosh S, Singh AK, Aruna B, Mukhopadhyay S, Ehtesham NZ (2003) The genomic organization of mouse resistin reveals major differences from the human resistin: functional implications. Gene 305: 27-34. [Crossref]

2. Yang RZ, Huang Q, Xu A, McLenithan JC, Eisen JA, et al. (2003) Comparative studies of resistin expression and phylogenomics in human and mouse. Biochem Biophys Res Commun 310: 927-935. [Crossref]

3. Fain JN, Cheema PS, Bahouth SW, Lloyd Hiler M (2003) Resistin release by human adipose tissue explants in primary culture. Biochem Biophys Res Commun 300: 674678. [Crossref]

4. Patel L, Buckels AC, Kinghorn IJ, Murdock PR, Holbrook JD (2003) Resistin is expressed in human macrophages and directly regulated by PPAR gamma activators. Biochem Biophys Res Commun 300: 472-476.

5. Steppan CM, Bailey ST, Bhat S, Brown EJ, Banerjee RR, et al. (2001) The hormone resistin links obesity to diabetes. Nature 409: 307-312. [Crossref]

6. Gerber M, Boettner A, Siedel B, Lammert A, Bar J, et al. (2005). Serum resistin levels of obese and lean children and adolescents: biochemical analysis and clinical relevance. J Clin Endocrinol Metab 90: 4503-4509. [Crossref]
7. Degawa-Yamauchi M, Bovenkerk JE, Juliar BE, Watson W, Kerr K, et al. (2003) Serum resistin (FIZZ3) protein is increased in obese humans. $J$ Clin Endocrinol Metab 88 5452-5455. [Crossref]

8. Filkova M, Haluzik M, Gay S, Senolt L (2009). The role of resistin as a regulator of inflammation: implications for various human pathologies. Clinical Immunology 133 157-170. [Crossref]

9. Gnacińska M, Małgorzewicz S, Stojek M, Łysiak-Szydłowska W, Sworczak K (2009) Role of adipokines in complications related to obesity: a review. Adv Med Sci 54: 150157. [Crossref]

10. Reilly MP, Lehrke M, Wolfe ML, Rohatgi A, Lazar MA, et al. (2005) Resistin is an inflammatory marker of atherosclerosis in humans. Circulation 111: 932-939. [Crossref]

11. Ohmori R, Momiyama Y, Kato R, Taniguchi H, Ogura M, et al. (2005). Associations between serum resistin levels and insulin resistance, inflammation, and coronary artery disease. J Am Coll Cardiol 46: 379-380. [Crossref]

12. Wang H, Chen DY, Cao J, He ZY, Zhu BP, et al. (2009) High serum resistin level may be an indicator of the severity of coronary disease in acute coronary syndrome. Chin Med Sci J 24: 161-166. [Crossref]

13. Momiyama Y, Ohmori R, Uto-Kondo H, Tanaka N, Kato R, et al. (2011). Serum resistin levels and cardiovascular events in patients undergoing percutaneous coronary intervention. $J$ Atheroscler Thromb 18: 108-114. [Crossref]

14. On YK, Park HK, Hyon MS, Jeon ES (2007) Serum resistin as a biological marker for coronary artery disease and restenosis in type 2 diabetic patients. Circ J 71: 868-873. [Crossref]

15. Chu S, Ding W, Li K, Pang Y, Tang C (2008) Plasma resistin associated with myocardium injury in patients with acute coronary syndrome. Circ J 72: 1249-1253. [Crossref]

16. Lubos E, Messow CM, Schnabel R, Rupprecht HJ, Espinola-Klein C, et al. (2007) Resistin, acute coronary syndrome and prognosis results from atherogene study. Atherosclerosis 93: 121-128. [Crossref]

17. Hu WL, Qiao SB, Hou Q, Yuan JS (2007) Plasma resistin is increased in patients with unstable angina. Chin Med J (Engl) 120: 871-875. [Crossref]

18. Zhang MH, Na B, Schiller NB, Whooley MA (2011) Association of resistin with heart failure and mortality in patients with stable coronary heart disease: data from the heart and soul study. J Card Fail 17: 24-30. [Crossref]

19. Wu XM, Lin YH, Chen A, Hsu TP, Wu YW, et al. (2012) Prognostic significance of adipocytokines in systolic heart failure patients. Eur J Clin Invest 42: 1079-1086. [Crossref]

20. Kreçki R, Krzemińska-Pakuła M, Peruga JZ, Szcześniak P, Lipiec P, et al. (2011) Elevated resistin opposed to adiponectin or angiogenin plasma levels as a strong, independent predictive factor for the occurrence of major adverse cardiac and cerebrovascular events in patients with stable multivessel coronary artery disease over 1-year follow-up. Med Sci Monit 17: CR26-32. [Crossref]

21. Yaturu S, Daberry RP, Rains J, Jain S (2006) Resistin and adiponectin levels in subjects with coronary artery disease and type 2 diabetes. Cytokine 34: 219-223. [Crossref]

22. Hoelfe G, Saely CH, Risch L, Koch L, Schmid F, et al. (2007). Relationship between the adipose-tissue hormone resistin and coronary artery disease. Clin Chim Acta 386: $1-6$.

23. Turgay Yildirim Ö, Yildirir A, Sade LE, Has Hasirci S, Kozan H, et al. (2018). Is there a relationship between resistin levels and left ventricular end-diastolic pressure? Anatol J Cardiol 19: 267-272. [Crossref]

24. Pischon T, Bamberger CM, Kratzsch J, Zyriax BC, Algenstaedt P, et al. (2005) Association of plasma resistin levels with coronary heart disease in women. Obes Res 13: 1764-1771. [Crossref]

25. Pilz S, Weihrauch G, Seelhorst U, Wellnits B, Winkelmann BR, et al. (2007) Implications of resistin plasma levels in subjects undergoing coronary angiography. Clin. Endocrinol. (Oxf.) 66: 380-386. [Crossref]

Copyright: $(2018$ Turgay Yıldırım Ö. This is an open-access article distributed under the terms of the Creative Commons Attribution License, which permits unrestricted use, distribution, and reproduction in any medium, provided the original author and source are credited. 